\title{
ELECTRICAL EQUIPMENT ANTITRUST CASES- THEIR IMPLICATIONS FOR GOVERNMENT AND FOR BUSINESS
}

\author{
MYRON W. WATKRNS $\dagger$
}

$\mathrm{B}$ ETWEEN FEBRUARY 16,1960, and September 15, 1960, a federal grand jury sitting in Philadelphia returned twenty-one indictments (since one superseded another, only twenty were the subject of controversy) charging conspiracy to fix prices, to "rig" bids, and to suppress competition among various groups of electrical equipment manufacturers in violation of the Sherman Act prohibition of all such schemes "in restraint of trade."1 These alleged conspiracies covered a long list of products used in the generation, transmission and industrial and residential application of electric current-ranging from simple items like porcelain insulators, lightning arresters, meters, and open fuse cutouts to such intricate devices as power switching gear, power capacitors, and turbine generators. These products comprised a large part, but not the whole, of the output of the electrical goods industry. Among important products, sales of which were not tainted by the conspiracies charged, were electric motors, electric lamps, and electric household appliances. The aggregate annual sales of the products which were the subject matter of the alleged conspiracies amounted to more than $\$ 1,700,000,000$ according to a Department of Justice estimate. (In what year, or the average for what years, not specified.) Taking 1958, a year covered by all the indictments, as representative, this figure represents approximately one-seventh of total corporate "business receipts" in the "Electrical Machinery and Equipment" industry as defined by the Internal Revenue Service.2

† Economist. A.B., 1914, University of Michigan; Ph.D., 1917, Comell University.

126 Stat. 209 (1890), as amended, 15 U.S.C. §§ 1-7 (1958).

2 Of the important qualifications on the use of Internal Revenue Service "industry" data as a basis for comparison with data of a single company generally regarded as a member of that industry, or of a group of such companies, two deserve mention here. First, some of the products specifically included among those classed as output of the given industry may be and often are manufactured by companies primarily engaged in producing other goods, and the revenue derived from such side line, or subsidiary, operations is reported accordingly as sales of these other industries. Thus, some electrical machinery, devices and equipment sales do not appear in the Internal Revenue Service figures on "business receipts" of "Electrical Machinery and Equipment Manufacturers." Per contra, some products not iechnically related to electrical equipment or apparatus are covered by the "Statistics of Income" figures on this "industry." U.S. TrEas. Dep't, Internal Revenue Servce, StaTISTICS OF INCOME-19 77-58, CORPORATION INCOME TAX RETURNS 6-14.

Secondly, the reporied total sales revenue of the industry exaggerates its actual value 
Each indictment charged several companies with violation of the antitrust laws and nine of them also charged with the same offense individual officers of those companies. Most of the twenty-nine corporate defendants were implicated in more than one market-control scheme; Westinghouse was implicated in all of them and General Electric in all but one. Of the forty-five individual defendants, sixteen were General Electric officers or employees of managerial rank and ten were Westinghouse executives or managers. These figures provide some clues to the active participation of the two giants of the industry in the challenged schemes.

On arraignment, March 24, 1960, Chief Judge Ganey of the United States District Court for the Eastern District of Pennsylvania rejected the petitions of the several company and individual defendants in the seven indictments returned prior to that date to enter pleas of, or to change previous pleas of not guilty to, nolo contendere. ${ }^{3} \mathrm{He}$ indicated, moreover, that in the disposition of the instant cases a nolo contendere plea would be treated as strictly equivalent to a plea of guilty.4 Upon the urgent recommendation of the Attorney General, he gave the petitioners only the option of pleading guilty or pleading not guilty and standing trial. It appears that "not guilty" pleas predominated on first arraignment. Thereafter, in the course of negotiations between government counsel and defense counsel, several defendants, including AllisChalmers and its company representatives who were individual defendants, apparently becoming convinced that their prospects of lenient treatment would be improved by saving the Department of Justice the trouble and expense of trying the case, or cases, against them and saving the court the tedium of a long trial, changed their initial pleas of not guilty to pleas of guilty. This break in the dike, along with the cumulative build-up of indictments covering additional phases of the business, increased the pressure on other defendants, and in particular General Electric and Westinghouse, to reach some agreement with the Department of Justice which would afford more assurance of eliminating the expense of trials and reducing the grave

product, because of double-counting. Whenever one company manufacturing electrical goods sells part or all of its output to another electrical goods manufacturer, the wholesale value of the goods is counted twice in the computation. With respect to the use of census data for the purpose indicated the first qualification mentioned above is equally applicable. However, substituting "value added by manufacture" data for "value of shipments" data obviates the second qualification, with respect to the use of census data.

3 United States v. Westinghouse Elec. Corp., 1960 Trade Cas. 69699 , at 76759 (E.D. Pa. March 24, 1960).

4 It appears that the only distinction of any practical significance between the two pleas is that a plea that a defendant will not contest the charges filed against him forestalls the use of this admission of guilt in the premises as prima facie evidence against him in a civil action by a third party for recovery of damages to his business resulting from the antitrust violation, whereas, under Section 5 of the Clayton Act, a plea of guilty, no less than a conviction after trial, has precisely that effect. 38 Stat. 731 (1914), as amended, 15 U.S.C. $\$ 16(1958)$. 
risks of treble-damage-suit liability in the event of conviction for the offenses charged. Eventually, in the fall the Department relented on its uncompromising insistence on a plea of guilty or not guilty and consented to give all defendants in thirteen of the cases the option of applying to the court for permission to enter nolo pleas, notwithstanding the inflexible position the court had taken on this point at the behest of the Attorney General in the March 24th hearings. 5 However, the Department put a condition, or proviso, on this relaxation of its procedural position; namely, that all defendants in the other seven cases plead guilty. Of course, this compromise arrangement between the parties was not binding on the court. At rearraignment hearings, called on November 17, 1960, Chief Judge Ganey decided to extend the option of applying for leave to enter a plea of nolo contendere from the thirteen less "serious" cases to the seven so-called "guilty" cases. 6

The outcome of the hearings, proceeding on this basis, was a qualified victory for the Government in that all defendants pleaded either guilty or nolo contendere in every one of the twenty cases. Furthermore, the largest two companies involved, General Electric and Westinghouse, carried out the mutually agreed arrangement with the Department by pleading guilty to each of the seven "most serious" cases, and nolo to the other thirteen. While in three of the seven "most serious" cases, the court accepted nolo pleas proffered by eight individual defendants, including two General Electric department managers, as well as nolo pleas proffered by five corporate defendants (Schwager-Wood and Joslyn Manufacturing in the power switching equipment case, Carrier Corporation in the condenser case, and Federal Pacific Electric and I-T-E Circuit Breaker in the oil circuit breaker case), these departures from the compromise settlement were in the end accepted by government counsel. Consequently, defendants were not required to face trial in any of the twenty cases and in so far they achieved, through the compromise settlement, one of its principal objectives.

Moreover, since the product sales involved in the seven "most serious"

$s$ This change in the Government's attitude toward nolo pleas in these cases was predicated, it asserted, primarily on two considerations. First, the change would facilitate expeditious disposition of the cases, thereby, in its view, increasing the deterrent effect on potential transgressors. Secondly, the change would involve a substantial saving in the resources of the Antitrust Division, since nolo pleas would obviate the need for twenty trials which, if held, were anticipated to run for several years involving large expense to the Government as well as to the defendants. Transcript of Hearings, November 17-22, p. 186, United States v. Westinghouse Elec. Corp., Criminal No. 20399 (E.D. Pa. 1960) [hereinafter cited as Transcript of Hearings].

The intense interest of the defendants in being permitted to enter nolo pleas stemmed, not so much from a belief that such a plea might alleviate the penalties imposed on them under the indictments, as from the circumstance that it would make it much more difficult for private parties who might institute treble damage suits to prove their case. See, e.g., id. at 215,228 . As mentioned, this flows from the prima facie evidence provision in Section 5 of the Clayton Act.

6 Id. at 190. 
cases represented, according to the government estimate, about seventy per cent of those tainted by the entire batch of twenty indictments, it follows that the compromise settlement relieved the defendants of a substantial part of the risk of contingent liability under the "prima facie" evidence rule in treble damage suits to which they might have been exposed. Of course, among the defendants General Electric and Westinghouse had most at stake on this score since their combined sales exceeded those of all the other twenty-seven corporate defendants. Hence the advantage the settlement afforded them was greater than that obtained by all the other defendants combined.

Accordingly, within a year after the Grand Jury handed up the first indictment, Chief Judge Ganey was enabled to dispose of the entire batch of twenty cases. For antitrust cases of such magnitude this dispatch in clearing the docket was itself an outstanding record, reflecting credit on Chief Judge Ganey as well as on the parties. On February 6-7, 1960, the court imposed aggregate fines of $\$ 1,721,000$ on the twenty-nine corporate defendants, and of $\$ 136,000$ on forty-five individual defendants, corporate officers or representatives. In addition, thirty-one of these individual defendants drew thirty-day jail sentences. Although twenty-four of these jail sentences were suspended, in seven instances the business culprits were actually incarcerated.

The severity of these penalties exceeded those imposed in any previous case, or batch of cases dealing with a single industry, in the seventy-year record of antitrust enforcement. Moreover, the imposition of a jail sentence which was required to be served on a theretofore reputable business executive who had pleaded nolo contendere to antitrust charges followed a precedent only five months old, which had upset a tradition of more than half a century. 7 It will be the principal objective of this paper to analyze the reasons for this outcome that has so shocked the business community and what it implies in terms of the development of antitrust policy on the one hand and of business policy on the other.

Within the statutory limits (fines up to $\$ 50,000$ and imprisonment up to one year, for each offense), the assessment of penalties is entirely a matter for judicial discretion. Although Chief Judge Ganey gave no clue to the reascins for imposing sentences of the exceptional severity described, it is a fair inf $: r$ ence from the fact that he adopted the Government's view of which indictments were the "most serious" ones that the criteria it avowedly employed in selecting the seven so-called "guilty" cases influenced his attitude in imposi.ng

7 So firmly had the custom become entrenched of imposing no heavier a penalty thar a fine on a businessman entering a plea of nolo contendere to a charge of price-fixing or mark rigging in collusion with rivals that such a limitation of the penaity had come to be wid-iy regarded as tantamount to a private right. See, e.g., United States v. McDonough Co., 1959 Trade Cas. \& 69482. at 75887-88 (S.D. Ohio Oct. 13, 1959). In this precedent-breaking ce se five corporate defendants and four of their officers, on pleas of nolo contendere to an indi : ment for having conspired to restrain trade in hand tools (shovels, rakes, hoes, etc.) wc $e$ fined altogether $\$ 110,000$, and each individual defendant was tequired to serve a ninety-d $y$ jail sentence. 
sentence. These criteria were: first, the magnitude and reach of the conspiracres charged, coupled with their persistence and flagrant character; secondly, their "public impact"; thirdly, the measures of concealment employed.

On their face, the first and second criteria represent different aspects of the same factor. The range of the markets tainted by the schemes is one way of measuring their "public impact."8 It may be assumed, accordingly, that one factor shaping the judgment was the size and structure of the electrical machinery and equipment industry.

The exact size of the industrial field within which the challenged schemes operated cannot be determined. The various products involved are scattered among many "industries" as classified by the Census Bureau. The nearest censal industrial category comparable with the cartelized field marked out by the instant cases is "Electrical Industrial Apparatus." In default of a better classification, data for this segment of the electrical machinery and equipment "industry" complex may be taken as a useful measure of the industrial scope of the indictments. The "value added by manufacture" in this "industry" complex in 1957 (the latest year for which data are available) was $\$ 3.75$ billion, 9 or about one-third of that of the entire group of industries engaged primarily in manufacturing electrical goods. Some indication of the "industry's" scale is afforded by the relationship of its "value added" to those of "petroleum refining" which was $\$ 2.8$ billion and of "pulp, paper, and board" manufacture, which was also $\$ 2.8$ billion. Another indication of relative magnitude is the number of production employees. "Electrical Industrial Apparatus" manufacturers employed 281,500 workers, companies engaged in "Petroleum Refining," 112,500 , and those engaged in manufacturing "pulp, paper and board," 188,800 .

From an antitrust standpoint, however, the structural pattern of an industry, or the degree of concentration, is even more significant than its size. General Electric is generally recognized as an outstanding example of a "leader" or "dominant" firm, in its field. Its annual sales (1957) of $\$ 4.0$ billion compare with aggregate "value added" (1957) of $\$ 9.6$ billion in the entire major group

8 True, this phrase was given a special connotation in the hearings. Government counsel emphasized that the schemes adversely affected, directly or indirectly, not only the interests of the general public as consumers, but also the costs of government inasmuch as governmental agencies were buyers of a substantial part of most of the products in question. The conspirators' derisory disregard of civic responsibilities and the public interest was evidenced not only in victimization of the military services, but also in mulcting such "welfare" agencies as TVA, the Department of the Interior, and the Atomic Energy Commission. In the case of public utility requests for competitive bids, one of the conspiratorial groups determined which confederate would be privileged to make the low bid by what was facetiously called "phase of the moon" distribution, a scheme providing for cyclical rotation of the privilege, so designed as to insure each member his agreed-upon share of the business.

9 U.S. Bureau of Census, Dep't of Commerce, Annual Survey of Manufacturers195726 (1958). This figure includes no double counting or inter-plant shipments. Accordingly, it is reasonably comparable with the gross sales or "business revenue" of individual companies operating in this field. 
of industries classified by the Census Bureau as "Electrical Machinery." Its most prominent confederate in the schemes attacked in the instant cases and for half a century its close collaborator and favored rival was Westinghouse. Together these corporate giants accounted for sales of $\$ 5.9$ billion in 1957, or the equivalent of more than 60 per cent of the "value added by manufacture" in the "Electrical Machinery" group of industries. ${ }^{10}$ This degree of concentration of industrial power is plainly incompatible with the smooth functioning of a competitive market. The classical theory of competitive ordering of markets contemplates the coexistence of a sufficient number of sellers not so disparate in size that a single one or group of two or three each acting independently, can exercise such a leverage on the market as to be able to control its course over relatively short periods. In recent decades economists have developed a theory of market behavior and price formation in such circumstances as prevail in the "Electrical Machinery" group of industries (i.e., a high degree of concentration of productive capacity, output, and sales). It is called the theory of monopolistic competition, and it teaches that free competition is unworkable under such oligopolistic conditions. Even if the big firms act independently each has a strong interest to avoid disrupting the market by setting relatively low prices, which, while they might be cost indemnifying to it, would probably be ruinous to smaller rivals or alternatively lead to price-cutting by a fellow-oligopolist, either surreptitously or openly and aggressively. On the other hand, to avert these nemeses there is a strong incentive in such circumstances to reach concerted agreement among all producers, big and small, to proceed on a "live and let live" basis.

An explanation along this line helps to clarify the record disclosed by the indictments in the instant cases. While collusion was frequent and widespread, it was repeatedly interrupted by internal differences of opinion on the right policy to be concertedly pursued or by charges and countercharges of alleged secret non-compliance with the nominally agreed prices and quotas.

Implicit judicial recognition of the leading role of the two giants of the industry in organizing and operating the instant conspiracies is reflected in many comments from the bench in the course of the hearings ${ }^{11}$ and even more clearly in the sentences imposed on those individual defendants who were General Electric and Westinghouse executives and/or managers. Of the $\$ 136,000$ aggregate fines imposed on individual defendants, General Electric officers were assessed the lion's share, viz., $\$ 47,000$, and Westinghouse officers the next largest total, $\$ 26,000$. Together these two groups found themselves liable for more than half the aggregate fines imposed on all the

10 A more precise comparison would be of company sales with industry sales, or "value of shipments," if the latter figure were available, purged of double-counting. But as explained hereinabove such data are not available. Indeed so extensive would be the doublecounting involved in compiling aggregate "value of shipments" in this field that the Bureau of Census declines to compute such a figure. Id. at 27.

11 See, e.g., the colloquy between the court and one of the defense counsel, in Transcript of Hearings, pp. 211-16. 
men who represented in these schemes their several corporate employers. But perhaps the clearest indication of the court's conclusion regarding the relative responsibility of the two Big Brothers of the industry, on the one hand, and of the score of small fry, on the other, is the distribution of the jail terms required to be served. Five of the seven such sentences imposed fell on members of the management hierarchy of either General Electric or Westinghouse.

Accordingly, though Chief Judge Ganey made no explicit reference to the oligopolistic structural pattern of the industry, as was quite proper since these indictments charged only collusive "restraint of trade" in violation of Section 1 of the Sherman Act, it is a legitimate inference from all the foregoing facts that in imposing sentences he was influenced not only by the size of the industry, but also by its oligopolistic structural pattern. What this evidently connotes is that we have in the instant cases something more than a judicial condemnation of a simple price-fixing or market-rigging conspiracy. We appear to have judicial recognition for the first time that oligopoly-plus-collusion represents a more flagrant infraction of the antitrust laws-more of a menace to a competitive business system-than mere mutual agreement among firms of substantially equal market leverage to refrain from competing.

Of course, no one except the Chief Judge himself can say for certain that the foregoing circumstances, suggesting the peculiar susceptibility of an oligopolistic pattern of industry structure to collusive arrangements and to erratic market performance, contributed signally to the shape of the judgment. But the hypothesis that it helps to explain the unusual severity of the sentences imposed would be wholly consonant with the Chief Judge's realistic approach to the question of ultimate responsibility for the illicit activities outlined in the indictments. 12

Doubtlessly aggravating the harshness of the judgment was the clandestine character of the schemes. Secrecy was carefully cultivated and sedulously safeguarded. ${ }^{13}$ To conceal their collusive arrangements, the corporate repre-

12 See, e.g., his inquiry regarding the danger of eliminating the competition of FederalPacific and other small companies, if they were penalized equally with General Electric and Westinghouse. Id. at 259. See also, his remarks regarding the activities of those individual defendants who were General Electric employees. "I have been struck with the attitude all along that if they were doing this meeting, making these arrangements, rigging prices and having these allotments made, certainly I am not naive enough to believe that General Electric didn't know about it and it didn't meet their hearty approbation." Id. at 264. Of course this is a stenographer's version of an off-hand observation from the bench. Doubtlessly the Chief Judge would have given his remark a more polished form if he had known it would be quoted.

13 It is significant that the company representatives who most assiduously cultivated secrecy and devised the most devious means of insuring it were General Electric officers. A good illustration is the arrangement for one of the conspiratorial meetings to be held in the resort region of Ontario. The G.E. representative took a separate cabin. Though he did not attend the meeting in an adjoining cabin where the other members of the group assembled, he was kept informed of the progress of the discussion by one of those "sitting in" who assumed the role of a "runner." His vote on the tentative decisions "sent up" for G.E. approval was obtained in this roundabout way. 
sentatives resorted to devices that could be said to match the tactics of the notorious Applachin gangsters. While the methods varied from one group to another, a common device was to assign each member of the group a code number or symbol. Communications were generally addressed to the homes, instead of the offices, of the several company representatives and mailed in envelopes bearing no return address or other means of identification. The rule prescribed was, without exception, to destroy all written communications promptly after receipt. ${ }^{14}$ It is indisputable that these conspirators knew what they were doing, and knew that their arrangements for fixing prices and for sharing the market in agreed proportions violated the law. The fact that they may also have believed that it was "good business" and, hence, that it would be condoned by top executives or by the directors under whom they served, who, in at least some instances were unaware of these clandestine proceedings, did not persuade either the Government or the court to take a lenient attitude toward their conduct.

The first inference that one may fairly draw from the outcome of these electrical equipment indictments is that if the Government wishes to vitalize the competitive business system, its first step should be to seek supplementation of Section 2 of the Sherman Act. Oligopolistic situations subject to specifically defined limitations would be proscribed, similarly to monopolies and "attempts to monopolize," as section 2 spells out an offense.15 Too long the intimate connection between oligopoly and collusion, to which Chief Judge Ganey's judgment has called attention, has been ignored.

But the outcome of these cases suggests a far more radical inference. It suggests, specifically, the urgent need for clarification, in both a legal and a practical sense, of the relationship between corporate managerial personnel of all ranks and the corporation itself. In respect to what matters and under what circumstances should there be a presumption that a particular corporate offcer or employee speaks and acts for his employer in the area of extra-corporate relations? The only statutory provision presently covering this matter is Section 14 of the Clayton Act, 16 the terms of which are quite indefinite-per-

14 No way was found, however, to insure compliance with this rule. If the members trusted in the axiom that there is honor even among thieves, they must have been disillusioned. For one of the principal sources of "ammunition" on which the government relied in laying down its barrage of twenty indictments was a cachet of such communications and memoranda stored up by one of the conspirators who eventually became disaffected. To "save his own skin" he turned state's evidence.

15 Approaching this issue obliquely, the Antitrust Division is insisting upon a rigorous supervision of pricing policy as one of the conditions for a consent decree in the companion civil suits. In default of acceptance of the conditions it has announced, it will seek dissolution if judgment after trial is in its favor. Westinghouse and Allis-Chalmers have agreed to the prescribed "conditions," but General Electric has announced it will fight these civil suits and take the risk of dissolution.

16 Section 14 provides that:

"Whenever a corporation shall violate any of the penal provisions of the antitrust laws, such violation shall be deemed to be also that of the individual directors, officers, or agents 
haps one should rather say ambiguous. On its face this section is directed to prescribing a rule determining when "directors, officers, or agents" are to be held accountable for corporate actions, whereas the need noted here is for a rule defining the subject matter and circumstances determining when the corporation is to be held accountable for the actions and commitments of "directors, officers" and employees or agents. Furthermore, the standards prescribed on the former issue appear to be too rigid for effective enforcement. Liability of "directors, officers, or agents" is conditioned upon positive proof of their having "authorized, ordered, or done" the acts charged to the corporation. Plainly, what is needed for the reverse issue is a rule prescribing the circumstances under which corporate liability may be predicated upon acts of "directors, officers, or agents" which have not been authorized or ordered. Likewise, how far may or should stockholders or directors be permitted to go: (1) in circumscribing the authority of particular officers to speak for the corporation, and (2) in delegating power to commit the corporation on certain subjects?

Much of the discussion in recent years regarding the advantages of decentralized management, or decentralized control, has ignored the risks it involves not only to company interests, but to general public interests. In these electrical equipment cases, the evidence strongly suggests that in at least one instance (and probably in others) decentralization was running wild. And the corollary is apposite: it was decentralization with a vengeance! The chief executive officer of General Electric has solemnly averred that he was not even aware of the conspiratorial arrangements that his subordinates were making, much less had he ever endorsed them. On the contrary, in intra-company conferences he had repeatedly impressed upon the company's personnel the obligation spelled out in a formal company policy rule (No. 20.5) adopted in 1954 , to avoid agreements and even discussions with representatives of other electrical goods manufacturing companies on prices, terms, or market shares. 17 Unquestionably, the primary object of this rule was to forestall such conspiratorial arrangements by General Electric representatives as these indictments disclosed. Was it, perchance, also designed to relieve the company and its top executives, in the event of its violation, of the opprobrium that attaches-and in the instant cases has attached-to attempts to control the market, while permitting the company (and indirectly its top executives) to reap the benefits of such unauthorized clandestine schemes pending their discovery and judicial condemnation? Let it be emphasized here that this is

of such corporation who shall have authorized, ordered, or done any of the acts constituting in whole or in part such violation, and such violation shall be deemed a misdemeanor, and upon conviction therefor of any such director, officer, or agent he shall be punished by a fine of not exceeding $\$ 5,000$ or by imprisonment for not exceeding one year, or by both, in the discretion of the court." 38 Stat. 736 (1914), 15 U.S.C. $\$ 24$ (1958).

17 Transcript of Hearings, p. 263. 
a simple inquiry; it is not a question loaded with suspicion and innuendo. The purpose is merely to raise the question of how far corporate policy decisions may properly and safely, from the standpoint alike of sound corporate management and of public policy, be decentralized, i.e., delegated among scores of scattered subordinate officers and even among employees having no official status-in the absence of any clear, definite and uniform rule of law applicable in the premises.

May not the subordinate General Electric personnel, who committed the company to the price-fixing and market-rigging schemes here complained of, and whom the Grand Jury indicated, have gained the impression from daily contacts with associates and superiors "on the spot" that Policy Rule No. 20.5 was a "front window" screen - and nothing more? On the basis of long experience, 18 could they not reasonably have come to believe that the company and the current roster of its top executives would welcome the lucrative returns from their market-control schemes and overlook the non-compliance with Rule No. 20.5? Chief Judge Ganey himself, as quoted hereinabove, appears to have shared the common skepticism that the indicated schemes could have been carried out over three, five, seven years, or longer without the company's board of directors and upper-echelon officers becoming aware of what was going on. Nevertheless, in default of adequate proof, the Government absolved members of the Board of Directors and top executives in the General Electric managerial hierarchy from complicity in the conspiracies for which the company was indicted. At the hearings on rearraignment for pleading, upon request of General Electric counsel, government counsel (Mr. Whittington) read the following statement:

18 In the past half century, prior to the instant indictments, the Department of Justice has hailed the company to court no less than nine times on charges of attempting to monopolize or restrain trade in violation of the Sherman Act. In only a single instance has its defense prevailed, and that was in a case primarily involving resale price maintenance in the distribution of incandescent electric lamps. A subsidiary issue in the same case was the lawfulness of its contract licensing Westinghouse to make and sell lamps under General Electric patents, subject to rigid output and price restrictions. United States v. General Elec. Co., 272 U.S. 476 (1926). It is only fair to say that the Supreme Court itself gave the company a clean bill of health on both scores. But faimess also requires noting that this judgment encountered a vigorous dissent, and that subsequently, on at least one occasion, the Court has implicitly questioned the soundness of the 1926 ruling (United States v. Masonite Corp., 316 U.S. 265 (1942)), and on another a formidable minority has challenged its validity and urged its repudiation. United States v. Line Materials Co., 333 U.S. 287, 315-21 (1948).

In the other eight cases, the company was either found guilty, or enjoined, or else in effect acknowledge guilt by pleading nolo contendere. In chronological order (by date of filing a complaint or indictment) these eight cases were: the incandescent lamp case (82) of 1911 ; the lamp bulb case (551) of 1940; the tungsten carbide case (650) of 1941; the incandescent lamp case (575) of 1941; the fluorescent lamp case (747) of 1942; the electric equipment (except lamps and radio apparatus) case (814) of 1945; the electric switches cases (915) (916) of 1948; and the street lighting equipment case (959) of 1948. The figures in parentheses refer to the case numbers in CCH, FEDERAI ANTIrRUST LAWS WITH SUMMARY OF CASES INSTITUTED BY THE UNITED STATES (1952), a compendium compiled by the Department of Justice. 
The Government has not charged and does not claim that any member of the General Electric Board of Directors, including Mr. R. J. Cordiner and Mr. Robert Paxton, had knowledge of the conspiracies pleaded in the indictments, nor does the Government claim that any of these men personally authorized or ordered commission of any of the acts charged in any of the indictments. 19

The two individuals specifically named were, at the time of the indictments, respectively, Chairman of the Board of Directors and President of the company. Though the next highest officer, in the fields of activity covered by the indictments, Mr. A. F. Vinson, Vice President and Group Executive, Apparatus and Industrial Group, was indicted for alleged participation in the power switchgear assemblies conspiracy, at the time of the rearraignment the Government filed a nolle prosequi motion as to him, which the court granted.20 Government counsel argued that a special investigation of his involvement in the conspiracy had brought to light evidence not available at the time the indictment was filed, which convinced it that a "reasonable doubt" existed in regard to his guilt. It might be argued that this shift in the Government's position regarding the knowledge and participation of one of the top three executives of General Electric is more persuasive of the difficulty in a complex corporate set-up of tracing responsibility to its source than it is of the utter innocence of these men. To say this is not to say, either that each or any of these men was probably aware, or that each or any of them was probably oblivious, of what was going on among their subordinates in the corporate managerial hierarchy. But it must be conceded that the Government's statement declining to make an issue of the personal involvement in the conspiracies charged of any member of the General Electric Board of Directors, including its top two executives, together with the reversal of its position regarding the involvement of the third highest executive, provides a good deal less than a clear and conclusive demonstration of the groundlessness of Chief Judge Ganey's skepticism "that General Electric didn't know about it (i.e., the regime of conspiratorial market manipulation in which the subordinate officers and employees admittedly participated)."21

To say this much is not to call in question the veracity of Mr. Cordiner or any other corporate defendant executive. It is merely to recognize an incontrovertible fact: that in the bewildering complexity and intricate ramifications of the administrative set-up in the modern "big business" corporation, the spheres of delegated authority and of managerial discretion are virtually impossible to disentangle. Moreover, it seems likely that neither the diversity and complexity of business situations nor a deliberate attempt to baffle outsiders is primarily responsible for this labyrinthine puzzle. The root of the

19 Transcript of Hearings, p. 414.

$20 \mathrm{Id}$. at 413.

21 Id. at 264. 
evil is the absence of uniform standards and rules for delegation of authority in these huge corporations in which, as the General Electric case shows, nobody appears to know who is responsible for what.22 Of course, with respect to assignment of credit for unforeseen improvements in profits or gains in market position it is much less difficult to trace responsibility than in assigning blame for untoward developments! In the maze of corporate officialdom it is as certain as anything can be in human behavior that accountability will seldom be acknowledged for any misdirection or misdoing whatever. ${ }^{33}$

So diverse and confusing are the lines of accountability of corporate management as countenanced under a congeries of fifty distinct state incorporation laws that evidently the sole way to restore responsibility in the conduct of corporate business on a large interstate scale is through a federal incorporation law, as recommended by President Taft fifty years ago. In his special

22 An illustration of the prevalent absence of clear lines of accountability from the lowest ranks in the management hierarchy up to corporate officers and directors is provided by the instant cases. The Gezeral Electric Board of Directors was so uncertain regarding whether it could be held liable for the misconduct (transgressing not only federal law but also Rule No. 20.5 of the company code) of those particular officers and employees who had been indicted that it called for a thorough study of the question by special counsel and withheld its pleas pending receipt of legal advice on this point and on the proposed pleading of individual General Electric personnel defendants. See Transcript of Hearings, p. 393.

23 See, for example, the parade of Pharisaical alibis in Transcript of Hearings, passim, most of which fall into one or the other of two categories:

(1) What, me? No, it was the higher-ups; I made no independent decisions; that was outside my province.

(2) What, me? No, it was those fellows lower down in the ranks. I knew nothing about what they were doing.

It is profoundly disturbing to discover that in such a representative big business unit as General Electric, the top two executives, both of whom were members of the company's Board of Directors, should acknowledge that they knew nothing of the manner in which their subordinates in the administrative hierarchy, to whom they had delegated responsibility for carrying out corporate policies in the conduct of specific functions, were actually discharging their assigned duties. See id. at 265. Apparently, the company business just "ran itself." In the management sphere, at least, it would appear that General Electric is in the avant garde of the automation movement.

The Assistant Attorney General in charge of the Antitrust Division saw in the misconduct revealed in these cases an even larger significance. Addressing the court regarding the alibis offered by defendants in Docket No. 20235, oil circuit breakers, one of the group of seven "guilty" cases, he observed: "These men and the companies involved here have in a true sense mocked the image of the economic system which we profess to the world. They have destroyed the model which we offer as a free-world alternative." Id. at 259.

This observation reminds of the conclusion reached in an earlier study: "What was once a way of life in the business world is fast becoming a way of rumination-or oratory. If competition is to survive it must be more than a shibboleth or a slogan. The discrepancy between the truths which men live by-in business-and the truths which they profess but do not live by is one of the most significant, and disturbing revelations of this survey." STOCKING \& WatKINS, CARTELS IN ACTION 13 (1946). It can now be told that this conclusion was framed fifteen years ago, with General Electric specifically in mind-on the basis primarily of its sponsorship of Phoebus, the international lamp cartel, and its monopolization of the tungsten carbide market. 
message to Congress on January 7,1910, he deciared: "If the prohibition of the antitrust act against combinations in restraint of trade is to be effectively enforced, it is essential that the National Government shall provide for the creation of national corporations to carry on a legitimate business throughout the United States."24 Just how rigid and how flexible should be the standards and rules of corporate accountability is a matter for congressional deliberation and decision. But one can well imagine Chief Judge Ganey addressing defendants in the instant cases, if he should eventually decide to write out an "opinion," as follows.

"Your counsel have been declaring that you cannot 'live' under a competitive regime. By the admitted facts in these cases it is equally clear that you cannot prosper under an oligopolistic regime. If I lay heavy sentences upon you

2418 Messages and Papers of the Presidents 7835. A more detailed and specific endorsement of the proposal came shortly afterward from one of the outstanding leaders of the bar in that period. See Morawetz, The Power of Congress to Enact Incorporation Laws and to Regulate Corporations, 26 HARv. L. REV. 667 (1913).

The indifference to this proposal which for five decades has marked the attitude in general of students of industrial organization and of public policy toward business may be traceable in part to misgivings regarding the constitutional basis for the proposed legislation. This is plainly a hold-over of nineteenth century dogmas regarding the relation of the state to industrial action. But see a series of articles by the present writer canvassing the question of the constitutionality of a congressional requirement of federal charters for giant corporations engaged in interstate commerce. Watkins, Federal Incorporation (pts. 1-3), 17 Mict. L. REv. 64, 145, 238 (1918-1919). However, the pressure of events is gradually dissolving these outmoded preconceptions. Thus, in the past few years, Congress first enacted and then expanded the Small Business Investment Companies Act in response to a demonstrated practical need, without bothering about the issue of constitutionality. 72 Stat. 691 (1958), 15 U.S.C. $\S 681$ (1958). For the legislative history see 2 U.S. CODE CONG. \& AD. News 2340 (1960). The act defines the powers of such corporations and provides for the issuance of federal charters after approval of articles of incorporation by the designated federal administrative authority, SBA.

Moreover, it is not only congressional opinion which has come to recognize federal responsibility for regulating business organization under the complex and highly integrated industrial conditions in the latter-day national economy. Judicial opinion also has reflected a growing awareness of the expediency of putting an end to the traditional toleration of state trespasses of this nature on an area reserved by the Constitution exclusively to federal control. The most persuasive exposition of the grounds for such legislation as found in the evils attending lax state incorporation laws was set down by Mr. Justice Brandeis in one of his epochal dissenting opinions. Louis K. Liggett Co.v. Lee, 288 U.S. 517, 557-59 (1933). As he explained, the root of the lax corporate discipline which prevails lies in the competition among the states for charter fees. A more specific indictment of the charter-mongering system that is the outcome of the neglect of Congress to exercise in this area its plenary power to "regulate interstate commerce" was handed up by Mr. Justice Rutledge. See his article Significant Trends in Modern Incorporation Statutes, 22 WASH. U.L.Q. 305 (1937). The sordid consequences of the lack of the uniform standards of organization and rules of operation that a federal incorporation statute could provide have been forcefully set forth in several opinions by Mr. Justice Cardozo, Mr. Justice Douglas and Mr. Justice Murphy in a series of cases in which corporate mismanagement has sometimes been condemned, notwithstanding the broad license given by state charters. McCandless v. Furland, 296 U.S. 140 (1935) (Cardozo, J.); Pepper v. Litton, 308 U.S. 295 (1939) (Douglas, J.); SEC v. Chenery Corp., 332 U.S. 196 (1947) (Murphy, J.). See also the illuminating and characteristically pungent concurring opinion of the late Judge Learned Hand in Morgan Stanley \& Co. v. SEC, 126 F.2d 325, 332-33 (2d Cir. 1942). 
for trying to make the oligopolistic regime work, by collusive arrangements, it is not to penalize you for your futile efforts, it is simply to apply the law that is invoked in these cases. The oligopolistic conditions under which you were endeavoring to find a prosperous, or at any rate a bearable, way of life are not challenged in these indictments. They may or may not be subject to effective challenge under the law as it stands (Sherman Act, Section 2). It is not within my province to sketch the outlines of a regime that might be 'workable" for you and at the same time salutary for the public. All that $I$ can do here is to emphasize the need for experimentation and search for such an industrial regime by levying sentences on you so onerous that they will focus attention -legislative, popular and business - on the anomaly of trying to make markets (either competitive or oligopolistic) work smoothly and salutarily simply by condemning collusion while leaving corporate structures to the vagaries of fifty charter-mongering states and the predilections of business organizers. The irony which these cases illuminate is that, with or without collusion, the electrical equipment markets as now organized manifestly will not function as the law contemplates. If the heavy penalties I am laying on you bring general recognition of that fact and open up to reexamination the whole question of workable rules for the conduct of business on the modern scale in the modern environment, they will have served their purpose." 